\title{
Utilization of Carbon Dioxide from Coal-Firing Flue Gas for Cultivation of Spirulina platensis
}

\author{
Oanh Thi Doan ${ }^{1}$, Anh Kim Thi Bui ${ }^{2}$, Kien Trung Hoang ${ }^{2}$, Chuyen Hong Nguyen², Thom Thi Dang ${ }^{2}$, \\ Hong Diem Dang, Nguyet Thi Vü ${ }^{2}$, Kim Dinh Dang ${ }^{2, *}$ \\ ${ }^{1}$ Ha Noi University of Natural Resources and Environment, Hanoi, Vietnam \\ ${ }^{2}$ Institute of Environmental Technology, Vietnam Academy of Science and Technology, Hanoi, Vietnam \\ ${ }^{3}$ Institute of Biotechnology, Vietnam Academy of Science and Technology, Hanoi, Vietnam
}

Email address:

doanoanh158@gmail.com (Oanh T. D.), buianh78@yahoo.com (Anh K. T. B.), hoangkien21@gmail.com (Kien T. H.), chuyenbi@gmail.com (Chuyen H. N), thomiet@gmail.com (Thom T. D.), ddhong60vn@yahoo.com (Hong D. D.), tranvunguyet@gmail.com (Nguyet T. V.), dangkim.iet@gmail.com (Kim D. D.)

${ }^{*}$ Corresponding author

\section{To cite this article:}

Oanh Thi Doan, Anh Kim Thi Bui, Kien Trung Hoang, Chuyen Hong Nguyen, Thom Thi Dang, Hong Diem Dang, Nguyet Thi Vu, Kim Dinh Dang. Utilization of Carbon Dioxide from Coal-Firing Flue Gas for Cultivation of Spirulina platensis. American Journal of Environmental Protection. Vol. 5, No. 6, 2016,pp. 152-156. doi: 10.11648/j.ajep.20160506.12

Received: October 14, 2016; Accepted: October 29, 2016; Published: November 18, 2016

\begin{abstract}
CO}_{2}$ emission from burning coal has been used as a carbon source for growing Cyanobacterium Spirulina platensis in order to minimize the cost of biomass production, and currently to carry out $\mathrm{CO}_{2}$ bioremediation. This article presents the results of feeding S. platensis in laboratory conditions with 2 formulas including Pure $\mathrm{CO}_{2}$ and Flue gas $\mathrm{CO}_{2}$ upon using modified Zarrouk's medium with $1.6 \mathrm{~g} / \mathrm{L} \mathrm{NaHCO}_{3}$ and $2 \mathrm{~g} / \mathrm{L} \mathrm{Na}_{2} \mathrm{CO}_{3}$. Pure $\mathrm{CO}_{2}$ with $1.2 \%$ concentrations taken from $99 \%$ vol of industrial $\mathrm{CO}_{2}$ and $\mathrm{CO}_{2}$ gas (1.2\%) received from the flue gas through the Modular system of Exhausted Gas Treatment (MEGT). Growth of the Cyanobacterium using $\mathrm{CO}_{2}$ - Flue gas is equivalent to $\mathrm{CO}_{2}-\mathrm{Pure}$. On this basis, $S$. platensis has been cultivated outdoor in an $25 \mathrm{~m}^{2}$ pond using $\mathrm{CO}_{2}$ gas $(1.2 \%)$ from the tunnel brick factory emissions after suitable cleaning. The experiment in an outdoor pond system of $25 \mathrm{~m}^{2}$ indicated that the yield of biomass is of $10 \mathrm{~g} / \mathrm{m}^{2} \mathrm{~d}$ with high-protein content $(62.58 \pm 2.34 \%)$ and fatty acids of high nutritional value $(8.72 \pm 0.14 \%)$, such as Omega - 6 and Omega - 3 reaching $14.74 \pm 0.42 \%$ and $26.05 \pm 0.64 \%$ of total fatty acid content, respectively. The quality of Spirulina cultured by $\mathrm{CO}_{2}$ gas meets the requirements for functional foods according to Vietnam national food standards. The article also presents the results of biomass productivity and chemical composition of the Cyanobacterium in different culture conditions.
\end{abstract}

Keywords: $\mathrm{CO}_{2}$, Carbon Source, Coal - Firing, Flue Gas, Cyanobacterium, Spirulina platensis

\section{Introduction}

$\mathrm{CO}_{2}$ - anthropogenic carbon dioxide represents the most important greenhouse gases (GHGs) that contribute to approximately $77 \%$ of the global atmospheric temperature increase $[1,2]$. The increase of $\mathrm{CO}_{2}$ concentration in the atmosphere, mainly due to burning fossil fuels like coal, oil, gas and the forest destroying raises the deep concern about the climate change, and thereby, induces great challenges to the global sustainable development $[3,4]$.

Burning coal generates more carbon dioxide than any other widely used fuel, including burning oil and gas that may harm the environment. Due to a rapid increase of the demand for the fossil fuels, there is a need for developing methods that allow continuous use of them through environmental friendly pathway along with reducing carbon dioxide emissions. In fact, there have been many efforts to reduce $\mathrm{CO}_{2}$ emissions from burning fossil fuels. Overall, the current methods are focusing on $\mathrm{CO}_{2}$ separation from emission sources and then trying to remove or capture it [5]. Some 
other technologies such as chemical absorption and membrane separation, were also considered [6]. However, these methods can significantly reduce $\mathrm{CO}_{2}$ concentration, they can not solve the problem of sustainable development [7].

Nowadays, in order to meet the demand for sustainable industrial development, it is highly desirable that exhaust emissions are treated thoroughly and sustainably through $\mathrm{CO}_{2}$ recovery for use in photosynthesis. The recovery of $\mathrm{CO}_{2}$ for microalgae culture is a novel pathway that has been studied and delivered in the reports. Lopes et al., 2008 indicated that as much as $40 \%$ of the carbon dioxide on the Earth can be absorbed by photosynthesis, in which microalgae or cyanobacteria make a great contribution with high species diversity and wide distribution in the ecological system [8]. So, photosynthesis by microalgae is an effective way to utilize $\mathrm{CO}_{2}$ sources [9].

The selected culture strains have a considerable impact on biological fixation of $\mathrm{CO}_{2}$ by level of temperature, $\mathrm{SO}_{\mathrm{x}}, \mathrm{NO}_{\mathrm{x}}$ and $\mathrm{CO}_{2}$ from flue gas [10]. Richmond mentioned that, cellular contents of Spirulina platensis were not changed by varying environmental conditions, compared with eukaryotic microalgae [11]. This alga is an excellent candidate for producing single cell protein due to its high protein content and nutritional value. Study on $S$. platensis due to potential of biomass production under high $\mathrm{CO}_{2}$ concentration in flue gas is a good solution for $\mathrm{CO}_{2}$ biofixation and for decreasing atmospheric $\mathrm{CO}_{2}[12,13]$.

Our objective is to assess the possibility of using $\mathrm{CO}_{2}$ from coal combustion emissions for the growth of Spirulina platensis.

\section{Materials and Methods}

\section{1. $\mathrm{CO}_{2}$ Source}

Pure $\mathrm{CO}_{2}$ with $1.2 \%$ concentrations taken from $99 \%$ vol of industrial $\mathrm{CO}_{2}$.

$\mathrm{CO}_{2}$ received from the flue gas through the Modular system of Exhausted Gas Treatment (MEGT) described is the page [14].

\subsection{Cyanobacterium and Cultivation Medium}

Spirulina platensis strain, classified as Arthrospira (Spirulina) platensis used for the experiments, was supplied from the Collection of Microalgae and Cyanobacteria of Institute of Environmental Technology, Vietnam Academy of Science and Technology.

Culture medium: The medium for the microalgal growth is Zarrouk's medium modified by reducing $\mathrm{NaHCO}_{3}$ to 1,36 $\mathrm{g} / \mathrm{L}$ and by adding $\mathrm{Na}_{2} \mathrm{CO}_{3}$ to $2 \mathrm{~g} / \mathrm{L}$ [15].

\subsection{Experimental Design}

Laboratory Cultivation: Spirulina platensis cyanobacteria is cultivated in glass columns with a volume of 1 liter (inner diameter of $60 \mathrm{~mm}$, height of $412 \mathrm{~mm}$ ) which are maintained at a temperature of $27-32^{\circ} \mathrm{C}$ and illuminated by cold fluorescent light with intensity of 5,000 lux, and lighting time of 8 hours/day (Fig. 1.a). The liquid columns of Cyanobacterium are continuously bubbled with $\mathrm{CO}_{2}$ - Flue gas $\left(1.2 \mathrm{vol} \% \mathrm{CO}_{2}\right)$ or $\mathrm{CO}_{2}$ - Pure as control experiments $(1.2$ vol. $\% \mathrm{CO}_{2}$ ), at a rate of $50 \mathrm{~L} / \mathrm{min}$ regulated by various valves. The $\mathrm{pH}$ of the medium is continuously controlled over time by $\mathrm{pH}$ equipment. Distilled water is added daily to eliminate evaporation effects during incubation.

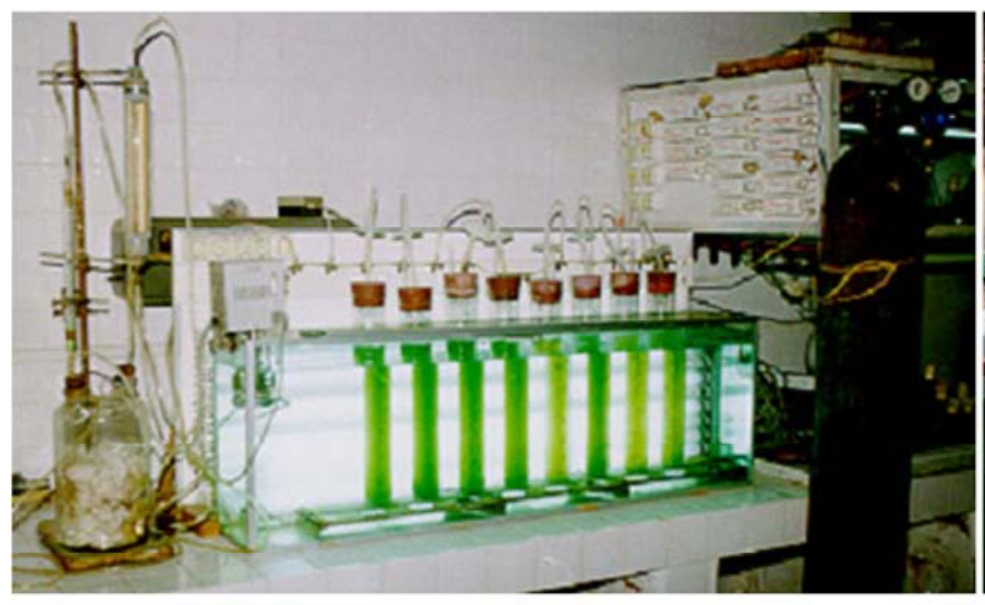

(a)

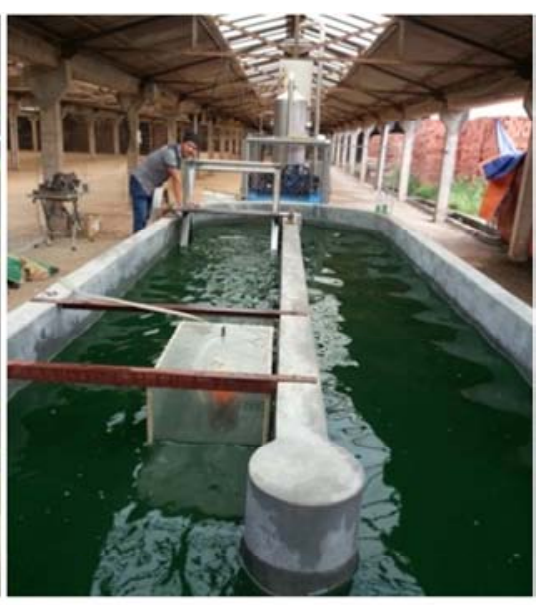

(b)

Fig. 1. Spirulina platensis culture system at laboratory conditions (a) and at outdoor conditions (b).

Spirulina platensis pond parameters have an area of $25 \mathrm{~m}^{2}$ with culture depth of $0.25 \mathrm{~m}$. This pond used $1.2 \% \mathrm{CO}_{2}$ from coal-fired flue gas which was cleaned via MEGT [14]. The experiments were carried out in 5 months (Fig. 1.b). The conditions for the Cyanobacterium culture: the average outdoor light intensity was about 25,000 lux, the temperature was in the range of $27-32^{\circ} \mathrm{C}$.
The $\mathrm{pH}$ of the suspension is maintained at $8.5-9.5$ and water is also added daily to eliminate evaporation effects. The pond was aerated by the paddle wheel system [16] in order to maintain moving speed of the suspension of about 18 $\mathrm{cms}^{-1}$. The samples containing the Spirulina suspension were collected every two days for OD measurement at wavelength of $445 \mathrm{~nm}$ using spectrophotometer UV-Vis 2450, Shimadzu, 
Japan. Each month, the fresh biomass of the Spirulina was collected for quality analysis.

\subsection{Sampling and Analysis}

Samples were collected for biomass growth analysis (OD) and biomass quality analysis (lipids, fatty acids, total protein, fiber (\%), carbohydrates, polysaccharide, ash, moisture and some important elements).

Lipids and fatty acids were analyzed according to the methods of Bligh and Dyer 1959 [17]. Total protein was determined by Kjeldahl method, multiplying by 6.25 . Fiber, carbohydrates, ash, moisture were determined by the method of analysis AOAC 2000 [18]. Arsenic, $\mathrm{Cd}, \mathrm{Pb}$ and $\mathrm{Hg}$ concentrations in Spirulina samples were measured using a Atomic Absorption Spectroscopy AA-6800, Shimadzu, Japan [19].

\subsection{Data Analysis}

All the data in mean and standard deviation were performed using Microsoft excel for Windows.

\section{Results and Discussion}

\subsection{Growth of S. platensis in Two Formulas: Pure - $\mathrm{CO}_{2}$ and Flue Gas - $\mathrm{CO}_{2}$ at the Laboratory Scale}

In the growth process, Spirulina platensis can use inorganic $\mathrm{C}$ sources under forms of $\mathrm{CO}_{2}, \mathrm{NaHCO}_{3}$ or $\mathrm{Na}_{2} \mathrm{CO}_{3}$ but the primary and most appropriate source is still $\mathrm{HCO}_{3}^{-}$ [13]. The supplementation of $\mathrm{CO}_{2}$ to the algae culture medium does not only provide $\mathrm{C}$ source but also control $\mathrm{pH}$ of the suspension. Fig. 2 presents the results of Spirulina platensis growth rate in 2 different formulas at the laboratory scale.

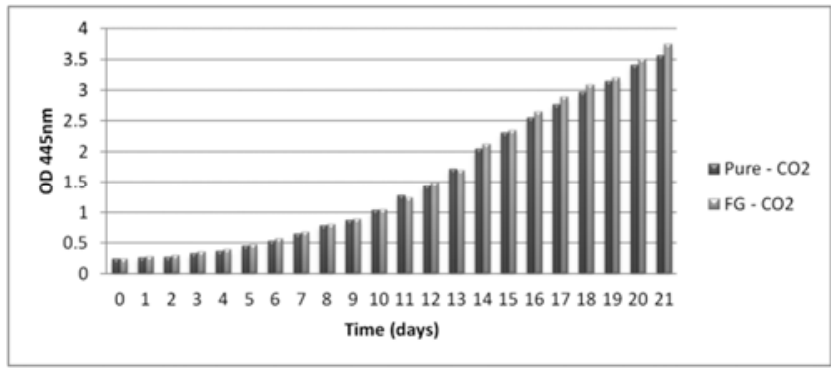

Fig. 2. The growth of Spirulina platensis with Pure $\mathrm{CO}_{2}$ and Flue gas $\mathrm{CO}_{2}$ at the laboratory scale.

After 21 days of experiment, Spirulina platensis increased biomass both in the 2 experimental formulas. Difference in Spirulina platensis biomass between two formulas (Pure $\mathrm{CO}_{2}$ and $\mathrm{FG} \mathrm{CO}_{2}$ ) is negligible. However, in the last week of the experiment, the growth of Spirulina platensis in FG- $\mathrm{CO}_{2}$ formula was slightly better than in Pure- $\mathrm{CO}_{2}$ formula. The achieved results may be explained that there is a small amount of $\mathrm{NO}_{\mathrm{x}}$ as nutrient for algae besides $\mathrm{CO}_{2}$ in the coal burning emissions [20].

In addition to assessing efficiency of the above 2 sources of $\mathrm{CO}_{2}$ on the growth of $S$. platensis, we also analyzed the nutritional composition of the biomass of this Cyanobacterium (Table 1).

Table 1. Chemical composition of fresh biomass of S. platensis cultured in different experimental formulas (per $100 \mathrm{~g}$ dry weight $\pm 5.43 \mathrm{~g}$ ).

\begin{tabular}{|c|c|c|c|c|c|c|c|}
\hline Parameters & Unit & Pure - $\mathrm{CO}_{2}$ & $\mathrm{FG}-\mathrm{CO}_{2}$ & Parameters & Unit & Pure - $\mathrm{CO}_{2}$ & $\mathrm{FG}-\mathrm{CO}_{2}$ \\
\hline Moisture & $\mathrm{g}$ & $2.51 \pm 0.04$ & $2.46 \pm 0.03$ & Lead $(\mathrm{Pb})$ & ppm & $0.54 \pm 0.02$ & $0.57 \pm 0.03$ \\
\hline Protein & $\mathrm{g}$ & $61.32 \pm 1.48$ & $61.21 \pm 1.34$ & Cadmium (Cd) & ppm & $<0.01$ & $<0.01$ \\
\hline Fat (Lipids) & $\mathrm{g}$ & $8.63 \pm 0.19$ & $8.68 \pm 0.12$ & Arsenic (As) & ppm & $0.13 \pm 0.01$ & $0.06 \pm 0.01$ \\
\hline Fibre & $\mathrm{g}$ & $0.4 \pm 0.05$ & $0.39 \pm 0.06$ & Mercury (Hg) & ppm & $<0.01$ & $<0.01$ \\
\hline Ash & $\mathrm{g}$ & $8.52 \pm 0.35$ & $8.64 \pm 0.27$ & Others & $\mathrm{g}$ & $18.62 \pm 1.22$ & $18.62 \pm 1.08$ \\
\hline Carotenoids & $\mathrm{mg}$ & $121 \pm 5.26$ & $149 \pm 6.62$ & & & & \\
\hline
\end{tabular}

The research results presented in Table 1 show that there is no difference in chemical composition of the biomass between two formulas and the use of $\mathrm{CO}_{2}$ from coal-fired emissions for Spirulina platensis cultivation has been proved to be advantageous, and could be applied in large scale.

\subsection{Growth and Productivity of Spirulina platensis in Culture Conditions at Dan Phuong, Hanoi}

Optical density (OD) measurement for Spirulina platensis growth was applied in our study. The $\mathrm{OD}_{445 \mathrm{~nm}}$ and dry biomass of the Spirulina platensis were determined every two days. The results in Fig. 3 demonstrated the variation of $\mathrm{OD}_{445 \mathrm{~nm}}$ of the culture suspension. On the first two days $S$. platensis grew slowly, the $\mathrm{OD}_{445 \mathrm{~nm}}$ value increased from 0.21 to 0.35 . After ten days, $S$. platensis grew rapidly from 0.34 0.35 to $1.09-1.11$. The highest level of $\mathrm{OD}_{445 \mathrm{~nm}}$ in this experimental process reached up to $1.67-1.73$ when the biomass harvest was performed for maintaining the algal OD relatively constant.

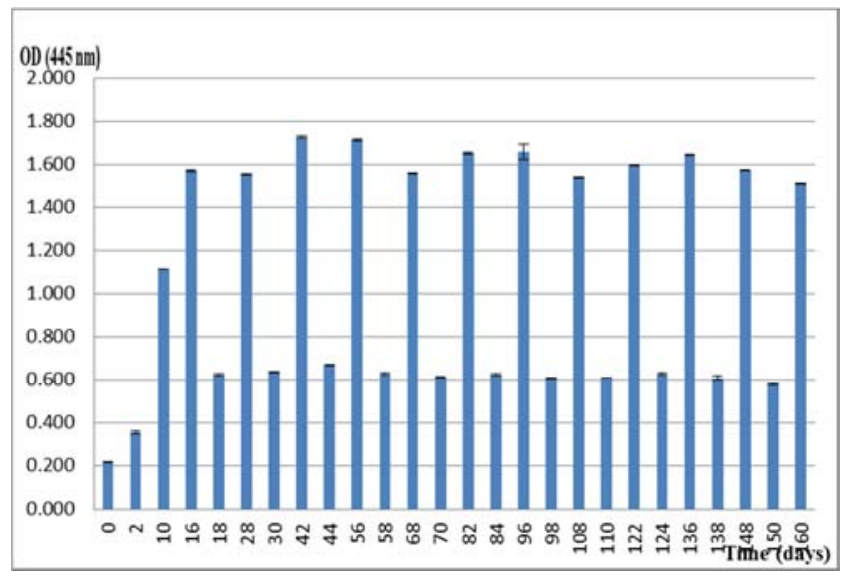

Fig. 3. Spirulina platensis' growth at outdoor conditions. 
Carbon dioxide is well adsorbed inside the $S$. platensis culture medium with $\mathrm{pH}>8.5$. During the photosynthesis, alkaline medium is normally created through the metabolic processes by phototrophic microorganisms participating in the transport of hydroxide ion $\left(\mathrm{OH}^{-}\right)$outwards its cell through catalytic reaction by carbohydrate anhydrase. As a result, the medium with phototrophic organisms as Spirulina platensis displays a strong alkaline property that helps them adsorb $\mathrm{CO}_{2}$ with high efficiency [21]. Therefore, there have been a lot of studies taking into account the microalgae using $\mathrm{CO}_{2}$ for nutritive biomass production. Cheng et al., (2006) has cultured Chlorella vulgaris in photobioreactor presenting that its growth rate is good in the medium with $1 \% \mathrm{CO}_{2}$ [22]. Aphanothece microscopica Nägeli (RSMan92) was cultured in tubular photobioreactors with different concentration of the carbon dioxide $(3,15,25,50$ and $62 \%)$, light intensity (960, 3000, 6000, 9000 and 11000 lux), and temperature $\left(21.5,25,30,35\right.$ and $\left.38.5^{\circ} \mathrm{C}\right)$ in order to determine the optimum condition, the highest $\mathrm{CO}_{2}$ absorption processes for this microalgae strain [8]. In the study of Sydney et al. (2010), Botryococcus braunii presented the highest $\mathrm{CO}_{2}$ fixation rate, followed by Spirulina platensis, Dunaliella tertiolecta, Chlorella vulgaris (as 496.98, 318.61, 272.4, and $251.64 \mathrm{mg} \mathrm{l}^{-1} \mathrm{~d}^{-1}$, respectively) [23].

In this research, flue-gas emissions from coal combustion contained $\mathrm{CO}_{2}$ with the amount around of $1.2 \%$. Using such a gas source for the algae production pond with the aeration time of 6 to $8 \mathrm{hr} \mathrm{d}^{-1}$ made the $\mathrm{pH}$ of their medium not to raise sharply, and keeps the $\mathrm{pH}$ unchanged in the range of 8.5-9.6. Additionally, using a modified Zarrouk's medium (the content of bicarbonate reduced to $1.6 \mathrm{gl}^{-1} \mathrm{NaHCO}_{3}$ and adding $2 \mathrm{gl}^{-1}$ carbonate $-\mathrm{Na}_{2} \mathrm{CO}_{3}$ ) in which $\mathrm{CO}_{2}$ extracted from coal-fired gas gave good results in Spirulina growth during the 180-day experiment.

For assessing the growth and productivity of $S$. platensis using $\mathrm{CO}_{2}$ in the outdoor conditions, the analysis of chemical composition in the Cyanobacterium biomass was also carried out (Table 2 and 3). The obtained results presented in Table 2 indicated that $S$. platensis was rich in protein, reaching up to $62.69 \%$ dry weight while the lipid content did not exceed $9 \%$.

Table 2. Biomass quality of S. platensis cultivated outdoor after spray drying (per $100 \mathrm{~g}$ dry weight $\pm 5.02 \mathrm{~g}$ ).

\begin{tabular}{llllll}
\hline Parameters & Unit & $\mathbf{C O}_{2}$ from flue gas via MEGT & Parameters & Unit & CO $_{2}$ from flue gas via MEGT \\
\hline Moisture & $\mathrm{g}$ & $2.39 \pm 0.04$ & Lead $(\mathrm{Pb})$ & $\mathrm{ppm}$ & $0.14 \pm 0.01$ \\
Protein & $\mathrm{g}$ & $62.58 \pm 2.34$ & Cadmium $(\mathrm{Cd})$ & $\mathrm{ppm}$ & $<0.01$ \\
Fat (Lipids) & $\mathrm{g}$ & $8.72 \pm 0.14$ & Arsenic $(\mathrm{As})$ & $\mathrm{ppm}$ & $0.04 \pm 0.01$ \\
Fibre & $\mathrm{g}$ & $0.43 \pm 0.03$ & Mercury $(\mathrm{Hg})$ & $\mathrm{ppm}$ & $<0.01$ \\
Ash & $\mathrm{g}$ & $9.83 \pm 0.06$ & Others & $\mathrm{g}$ & $16.05 \pm 0.97$ \\
Carotenoids & $\mathrm{mg}$ & $44 \pm 3.44$ & & & \\
\hline
\end{tabular}

Moreover, the Spirulina also contained fatty acids having high nutritional value, such as Omega - 6 and Omega - 3 which reached $14.74 \%$ and $26.05 \%$ of total fatty acid content, respectively (Table 3 ).

Table 3. Composition of fatty acids in biomass after spray drying.

\begin{tabular}{|c|c|c|}
\hline Fatty acids & Scientific name & Quantity (\%) \\
\hline $14: 0$ & Pentadecanoci acid & ND \\
\hline $16: 0$ & Hexadecanoic acid & $45.48 \pm 1.24$ \\
\hline $16: 1 n-7$ & 9-Hexadecenoic acid & $4.43 \pm 0.12$ \\
\hline $17: 0$ & Heptadecanoic acid & ND \\
\hline $17: \ln -5$ & Heptadecenoic acid & ND \\
\hline 18:0 & Octadecanoic acid & ND \\
\hline $18: 1 n-6$ & Octadecenoic acid & $3.59 \pm 0.08$ \\
\hline $18: 3 n-3$ & $9,12,15$-octadecatrienoic acid & $26.05 \pm 0.64$ \\
\hline $18: 3 n-6$ & $6,9,12$-octadecatrienoic acid & $14.74 \pm 0.42$ \\
\hline 20:0 & Eicosanoic acid & $5.71 \pm 0.09$ \\
\hline $20: 3 n-6$ & 11,14,17-eicosatrienoic acid & ND \\
\hline $20: 4 n-6$ & 5,8,11,14-eicosatetraenoic acid & ND \\
\hline
\end{tabular}

ND: non detection

As shown in Fig. 3, during the experimental production of the Spirulina at the outdoor conditions, the Cyanobacterium was harvested when $\mathrm{OD}_{445}$ values achieved about 1.6 with the productivity of about $10 \mathrm{~g} / \mathrm{m}^{2} \mathrm{~d}$. This showed that the using $\mathrm{CO}_{2}$ from coal-fired flue gas for culturing Spirulina platensis is feasible for mass culture.

The quality of Spirulina cultured by $\mathrm{CO}_{2}$ gas from coal- fired flue gas of the Tuynel Brick Factory is good and equivalent to that of Siam Algae Company (SAC) assessed by Japan Food Researcher Laboratories [24]. Heavy metal concentrations, including $\mathrm{Pb}, \mathrm{Cd}, \mathrm{As}, \mathrm{Hg}$, and the others (Table 2), of the Spirulina remained within acceptable limits for functional foods according to the Decision No. 46/2007/QD-BYT and VNNTR 8-2:2011/BYT (Vietnam) $[25,26]$. This is an important basis for using Spirulina as a nutritive food or functional food source for humans. In the context of global climate change, Spirulina platensis not only makes a positive contribution to reducing greenhouse gases $\mathrm{CO}_{2}$ but could be also good biomass for different purposes.

\section{Conclusion}

At the laboratory scale, biomass growth and quality of Spirulina platensis in 2 formulas (Pure $\mathrm{CO}_{2}$ and Flue gas $\mathrm{CO}_{2}$ ) are equivalent. The experiment in an outdoor pond system of $25 \mathrm{~m}^{2}$ indicated that the yield of biomass is of $10 \mathrm{~g} / \mathrm{m}^{2} \mathrm{~d}$ with high-protein content of $62.58 \pm 2.34 \%$ and fatty acids of high nutritional value $(8.72 \pm 0.14 \%)$, such as Omega -6 and Omega - 3 reaching $14.74 \% \pm 0.42$ and 26.05 $\pm 0.64 \%$ of total fatty acid content, respectively. The obtained results allowed evaluating the potential of using $\mathrm{CO}_{2}$ from coal combustion emissions for $S$. platensis culture with cost effective way for carbon sources and also for environment protection. 


\section{Nomenclature}

GHGs: Greenhouse Gases

MEGT: Modular system of Exhausted Gas Treatment

OD: Optical Density

VNNTR: Viet Nam National technical regulation

\section{Acknowledgements}

This work was financially supported by The National Project KC08.08/11-15, Ministry of Science and Technology (MOST), Vietnam.

\section{References}

[1] IPCC - The United Nations Intergovernmental Panel on Climate Change: Climate Change 2007 Mitigation. (2007) Contribution of Working Group III to the Fourth Assessment Report of the Intergovernmental Panel on Climate Change [B. Metz, O. R. Davidson, P. R. Bosch, R. Dave, L. A. Meyer (eds)], Cambridge University Press, Cambridge, United Kingdom and New York, NY, USA, 841 pp.

[2] Juan, C. L., Guillermo, Q., Theo, S. O. S., José, M. E., Raquel, L., Raúl, M. (2013) Biotechnologies for greenhouse gases $\left(\mathrm{CH}_{4}, \mathrm{~N}_{2} \mathrm{O}\right.$, and $\left.\mathrm{CO}_{2}\right)$ abatement: state of the art and challenges. Appl Microbiol Biotechnol 97: 2277-2303.

[3] Maroto-Valer, M. M., Song, C., Soong, Y., (Eds). (2002) Environmental Challenges and Greenhouse Gas Control for Fossil Fuel Utilization in the $21^{\text {st }}$ Century. Kluwer Academic/Plenum Publishers, New York, 447 pp.

[4] Song, C., Gaffney, A. M., Fujimoto, K., (Eds). (2002) $\mathrm{CO}_{2}$ Conversion and Utilization. American Chemical Society (ACS), Washington DC, ACS Symp Series Vol 809448 pp.

[5] Iglesias-Rodríguez, M. D., Halloran, P. R., Rickaby, R. E. M., Hall, I. R., Colmenero-Hidalgo, E., Gittins, J. R., Green, D. R. H., Tyrrell, T., Gibbs, S. J., Dassow, P. V., Rehm, E., Armbrust, E. V., Boessenkool. K. P. (2008) Phytoplankton Calcification in a High- $\mathrm{CO}_{2}$ World. Science 320 (5874): 336340 .

[6] Aiba, S., Ogawa, T. (1997) Assessment of growth yield of a blue-green alga: Spirulina platensis, in axenic and continuous culture. J of General Microbiology 102: 179-182.

[7] Kim, D. D., T. V. Tua, N. T. Cu, D. T. Anh, D. T. Thom, H. T. Kien, L. T. T. Thuy, T. V. Nguyet, M. T. Chinh, \& N. V. Vuong. (2011) Utilization of $\mathrm{CO}_{2}$ captured from the coal-fired fuel gas for growing Spirulina platensis SP4. Journal of Science and Technology 49 (4): 65 - 72 ISSN 0866 708X.

[8] Lopes, E. J., Scoparo, C. H. G., Franco, T. T. (2008) Rates of $\mathrm{CO}_{2}$ removal by Aphanothece microscopica Nageli in tubular photobioreactors. Chemical Engineering and Processing 47: 1365-1373.

[9] Uday, B. S., Ahluwalia, A. S. (2013) Microalgae: a promising tool for carbon sequestration. Mitig Adapt Strateg Glob Change 18: 73-95.

[10] Kumar, K., Dasgupta, C. N., Nayak, B., Lindblad, P., Das, D. (2011) Development of suitable photobioreactor for $\mathrm{CO}_{2}$ sequestration addressing global warming using green algae and cyanobacteria. Bioresour Technol 102: 4945-4953.
[11] Richmond, A. (2013) Handbook of microalgal culture: biotechnology and applied phycology. 3rd ed. Oxford: Blackwell Science Ltd.

[12] Seyedmahdi, H., Saeed, A., Mohamad, S. H., Fatemeh, M. (2014) Growth response of Spirulina platensis PCC9108 to elevated $\mathrm{CO}_{2}$ levels and flue gas. Biological Journal of Microorganism, 29- 36.

[13] Song-Gun, K., Chan-Sun, P., Yong-Ha, P. (2004) Effect of $\mathrm{CO}_{2}$ Concentration on Growth and Photosynthesis of Spirulina platensis. Studies in Surface Science and Catalysis, 153: 295-298.

[14] Nguyet M. T. T., et al,. (2013) Application studies on catalytic nano materials for removal of hazardous gases. Journal of Catalysis and adsorbent, 3: 136-142.

[15] Aiba S., Ogawa T., 1997. Assessment of growth yield of a blue-green alga: Spirrulina platensis, in axenic and continuous culture. J. Gen. Microbiology, 10: 179-182.

[16] Masoji'dek, J., Torzillo, G. (2014) Mass Cultivation of Freshwater Microalgae. Reference Module in Earth Systems and Environmental Sciences, 13 pp.

[17] Bligh, E. G., Dyer, W. J. (1959) A rapid method for total lipid extraction and purification. Can J Biochem Physiol 37: 911917.

[18] Official Methods of Analysis. (2000) 17th Ed., AOAC INTERNATIONAL, Gaithersburg, MD.

[19] Horwitz, W. (2000) Official method of analysis of AOAC International. Published by AOAC International Suite 500, 481 North Frederick Avenue, Gaitherburg, Maryland 208772471, USA.

[20] Negoro, M., Shioji, N., Miyamoto, K. and Miura, Y. (1991) Growth of microalgae in high $\mathrm{CO}_{2}$ gas and effects of $\mathrm{SO}_{\mathrm{x}}$ and $\mathrm{NO}_{\mathrm{x}}$. Appl. Biochem. Biotechnol., 28/29, 877-886.

[21] Simona, A., Carlo, S., Alessandra, L., Adriana, D. B. (2013) Spirulina platensis Culture with Flue Gas Feeding as a Cyanobacteria-Based Carbon Sequestration Option. Chem Eng Technol 36 (1) 91-97.

[22] Cheng, L., Zhang, L., Chen, H., Gao, C. (2006) Carbon dioxide removal from air by microalgae cultured in a membrane-photobioreactor. Separation and Purification Technology 50: 324-329.

[23] Sydney, E. B., Sturm, W., Carvalho, J. C., Soccol, V. T., Larroche, C., Pandey, A., Soccol, C. R. (2010) Potential carbon dioxide fixation by industrially important microalgae. Bioresource Technology 101: 5892-5896.

[24] Hidenori, S. (2004) Mass production of Spirulina, an edible microalga. Asian Pacific Phycology in the 21 st Century: Próspects and Challenges Developments in Hydrobiology 173 $39-44$.

[25] Decision No. 46/2007/QD-BYT dated December 19, 2007 of the Viet Nam Ministry of Health on Promulgation regulation of maximum level of biological and chemical pollution in food.

[26] VNNTR 8-2: 2011/BYT of the Viet Nam Ministry of Health on National technical regulation on the limits of heavy metals contamination in food. 